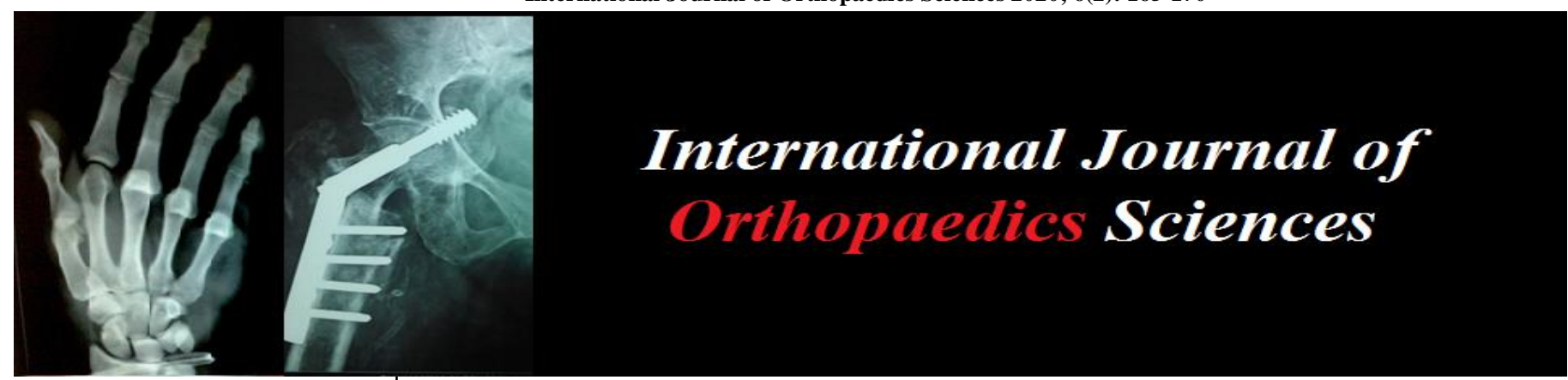

E-ISSN: 2395-1958

P-ISSN: 2706-6630

IJOS 2020; 6(2): 165-170

(C) 2020 IJOS

www.orthopaper.com

Received: 08-01-2020

Accepted: 12-02-2020

Dr. A Sureshkumar

Department of Orthopaedics,

Tirunelveli Medical College,

Tirunelveli, Tamil Nadu, India

\section{Dr. S Dinesh}

Assistant Professor, Department of Orthopaedics, Tirunelveli Medical College, Tirunelveli, Tamil Nadu, India

\section{Dr. G Venkatesh}

Department of Orthopaedics,

Tirunelveli Medical College,

Tirunelveli, Tamil Nadu, India

\section{Role of percutaneous vertebroplasty in osteoporotic compression fractures: A prospective study}

\author{
Dr. A Sureshkumar, Dr. S Dinesh and Dr. G Venkatesh
}

DOI: https://doi.org/10.22271/ortho.2020.v6.i2c.2032

\section{Abstract}

Background: Osteoporotic vertebral compression fractures have gradually evolved into serious health care problem globally. Vertebroplasty is an outpatient procedure for OVCF.

Materials and methods: Our Prospective Study Consists of Twenty Patients of Which Fifteen Wre Female and Fiove Were Male. Percutaneous Vertebroplasty Was Done In Single Level For 14 Patients Double Level For 4 Patients And Three Level For 2patients.

Results: Results After 2 Year Follow up Was Excellent In 14 Patients Good In 3 Patients Fair In 1 Patient. 2 patients had cement leakage.

Conclusion: Percutaneous vertebroplasty is a technically feasible treatment in patients with osteoporotic compression fractures which doesn't respond to the best possible conservative treatment. Percutaneous vertebroplasty works as internal splint for the microfractures of vertebral body by methyl methacrylate cement which helps to relief severe pain.

Keywords: Vertebroplasty, osteoporotic compression fractures, PMMA

\section{Introduction}

Vertebral Compression Fractures are commonest complications of osteoporosis. It causes progressive pain, deformity, disability and finally affecting the quality of life and morbidity. Standard conservative treatment consists of analgesics, bed rest and use of braces. Though it reducers pain dependence of drugs and narcotics progressively increases. Also prolonged recumbency further leads to bone loss, kyphotic deformity and limitation of activities of life. Percutaneous vertebroplasty is an recent development in the treatment of compression fractures using high viscosity PMMA. The goal of vertebroplasty is conferring strength and stability of vertebra. Percutaneous vertebroplasty is currently used in the treatment of osteoporotic as well as steroid induced compression fractures, spine metastasis, and vertebral haemangiomas.

\section{Materials and Methods}

Our study is prospective which analyses the functional and radiological outcome of percutaneous vertebroplasty in the treatment of vertebral osteoporotic compression fractures in patient who were treated in Tirunelveli government medical college and hospital with percutaneous vertebroplasty from July 2015 to September 2017 with total duration of 24 months

\section{Inclusion Criteria}

1. AGE above $60 y r s$

2. Pain due to compression fracture not subsided after 3 weeks of medical management

\section{Exclusion Criteria}

1. Active infection

2. Atypical fracture pattern

3. Unstable fracture involving posterior elements 


\section{Patient Evaluation}

A physical examination is performed to document the exact site of the patient's pain and tenderness, the patient's baseline peripheral neurologic examination, and to detect any unrecognized weakness, neurologic impairment, or other factor which may require intervention, or which places the patient at increased risk if leakage of cement occurs.

\section{Radiological Evaluation: X-RAY CT and MRI}

\section{Surgical techniques}

The image intensifier is aligned so that the endplates of vertebra are sharp and spinous process is midline for the true AP projection. The lateral margin of pedicle is targeted by the needle in this projection at the 9 o'clock position for the leftsided approach and 3 o'clock position for right-sided approach. The needle is then embedded $2-3 \mathrm{~mm}$ into bone using either the orthopedic mallet or the hand screwing motion. The image intensifier is turned to true lateral projection. The needle may now be advanced in lateral projection to a point approximately $1 \mathrm{~cm}$ short of purpose of not advancing the needle to anterior cortex of the vertebral body on lateral projection is to avoid breaching anterior margin of vertebral body

Free flow of Normal saline injection on contralateral cannula indicate intravertebral cavity. Inject the cement in lateral projection with continuous fluoroscopic monitoring and cement consistency should be similar to the toothpaste. There should be no shine to cement's appearance as this signify that it is thin. The greatest attention should be at posterior margin of vertebral body at epidural space. The operator should stop cement injection if cement reaches beyond $5 \mathrm{~mm}$ anterior to posterior margin of vertebral body. The cement volume should be no more than the $1 \mathrm{cc}$ on each side for high thoracic (total $<2 \mathrm{cc}$ ), $2 \mathrm{cc}$ on each side for low thoracic (total $<4 \mathrm{cc}$ ), and no more than the $3 \mathrm{cc}$ on each side for a lumbar (total $<6 \mathrm{cc}$ ), with goal being top to the bottom filling on each side. sides.

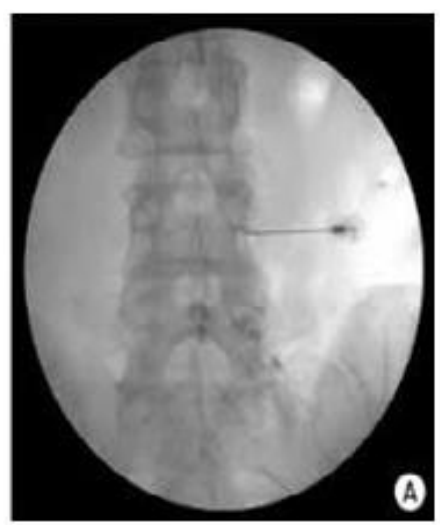

AP View

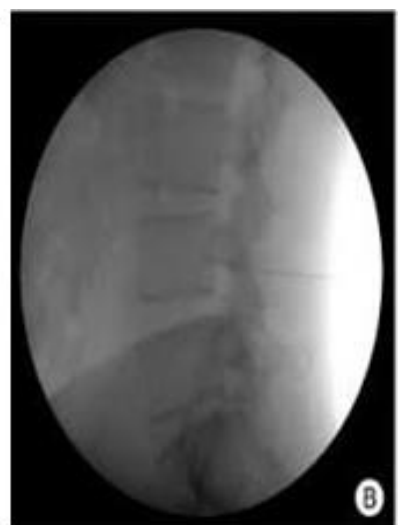

Lateral View
Fig 1: Anatomical Orientation
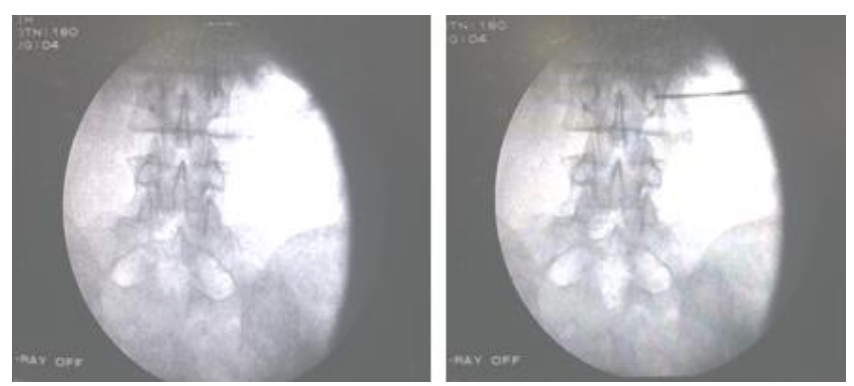

Fig 2: Marking the entry point
After completion of procedure patients were instructed to lie supine for $2 \mathrm{hr}$. Throughout the procedure and after that constant watch was kept on neurological status. Before discharging patient asses for improvement of pain immediately after the procedure and at $24 \mathrm{hrs}$ then patients were observed for the presence of neurological deficit and any complication. All patients are evaluated after $8 \mathrm{hr}, 3^{\text {rd }}$ post op, $1^{\text {st }}$ month, $3^{\text {rd }}$ month after 1 yr with Roland morris disability questionarre $\&$ visual analog scale
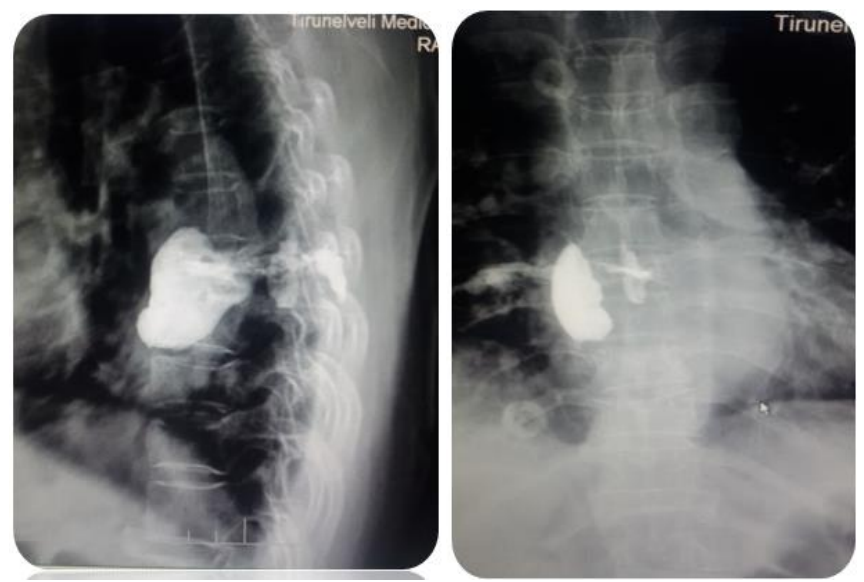

Fig 3: Complications

In our study two cases had Cement leakage into the disc and paravertebral region. Patients are treated with analgesics.

\section{Results}

Table 1: Immediate post-procedure result

\begin{tabular}{|c|c|c|}
\hline Clinical Status & No of patients & Percentage \\
\hline Asymptomatic & 14 & 70 \\
\hline Improved & 2 & 10 \\
\hline Static & 2 & 10 \\
\hline Detoriated & 2 & 10 \\
\hline
\end{tabular}

At immediate post procedure period 14 patients were pain free and asymptomatic, 02 patients showed improvement. Two patients were static.

Table 2: The pain score, activity level, analgesic intake

\begin{tabular}{|c|c|c|c|c|c|}
\hline & \multicolumn{2}{|l|}{ PR vertebroplasty } & \multicolumn{3}{|c|}{ Post vertebroplasty } \\
\hline & Mean & $\begin{array}{c}\text { Standard } \\
\text { deviation }\end{array}$ & Mean & $\begin{array}{c}\text { Slandered } \\
\text { deviation }\end{array}$ & $\begin{array}{c}\text { p- } \\
\text { value }\end{array}$ \\
\hline Pain & 6.26 & 1.75 & 1.59 & 1.99 & 0.0001 \\
\hline Activity score & 1.38 & 1.41 & 0.53 & 1.23 & 0.0187 \\
\hline $\begin{array}{c}\text { Medication } \\
\text { Score }\end{array}$ & 1.15 & 0.99 & 0.41 & 0.56 & 0.0003 \\
\hline
\end{tabular}

Mean preoperative VAS score was $5.91 \pm 2.07$ (SD), and their mean postoperative VAS scores were $3.5 \pm 2.22$ (SD). Pairedsamples $\mathrm{t}$ testing of preoperative versus postoperative VAS scores were significantly different $(P<0.001)$. The analgesic intake after the procedure was statistically significant $(p<$ $0.001)$

Table 3: Three months post-procedure result

\begin{tabular}{|c|c|c|}
\hline Clinical Status & No of patients & Percentage \\
\hline Asymptomatic & 16 & 80 \\
\hline Improved & 1 & 5 \\
\hline Static & 1 & 5 \\
\hline Detoriated & 2 & 10 \\
\hline
\end{tabular}


At three months 16 patients were asymptomatic and 3 patients show clear improvement. One patient had static course.

Table 4: The pain score, activity level, analgesic intake

\begin{tabular}{|c|c|c|c|c|c|}
\hline & PR vertebroplasty & \multicolumn{3}{|c|}{ Post vertebroplasty } \\
\hline & Mean & $\begin{array}{c}\text { Standard } \\
\text { deviation }\end{array}$ & Mean & $\begin{array}{c}\text { Standard } \\
\text { deviation }\end{array}$ & p-value \\
\hline Pain & 6.26 & 1.75 & 0.24 & 0.99 & 0.0001 \\
\hline $\begin{array}{c}\text { Activity } \\
\text { score }\end{array}$ & 1.38 & 1.41 & 0.26 & 0.79 & 0.0002 \\
\hline $\begin{array}{c}\text { Medication } \\
\text { Score }\end{array}$ & 1.15 & 0.99 & 0.06 & 0.24 & 0.0001 \\
\hline
\end{tabular}

There is significant improvement of pain activity, physical activity and medication score at 3 month follow-up

Table 5: Follow up result at 12 months

\begin{tabular}{|c|c|c|}
\hline Clinical Status & No of patients & Percentage \\
\hline Asymptomatic & 18 & 90 \\
\hline Improved & 1 & 5 \\
\hline Static & 1 & 5 \\
\hline Detoriated & 0 & 0 \\
\hline
\end{tabular}

At 12 months 18 patients were asymptomatic, 1 patient showed improvement, 1 patient had a static course. The patient who had static course underwent pain medication and osteoporosis management.

In our study among 20 patients, 18 patients shows good improvement in pain as well as in day today activities. 2 Patients had complication of cement leakage in disc \& paravertebral Space, Who are all treated with analgesics shows improvement after one year of follow up.

\section{Discussion}

Osteoporosis usually remain silent and,just one third of the patients with osteoporotic Vertebral compression fractures are symptomatic. when a painfull VCF occurs, symptoms should be treated and predictable complications should be avoided. Both acute and chronic complications have been described. Postural changes associated with kyphosis may limit activity, including bending and reaching. Moreover, restrictive lung disease may arise when multiple thoracic fractures occur. Although the osteoporotic VCF have a multifactorial aetiology, bone mineral density (BMD)is the central component of any management plan. Osteoporosis is marked by bone deficiency status, defined with the BMD measurements $>2.5$ standard deviations below average peak bone mass. the term severe osteoporosis is defined as an osteoporosis status associated with the osteoporotic fragility fractures. Osteoporotic fragility fractures are defined as occurring at the site associated with low BMD; they have increased incidence after age of $50 \mathrm{yrs}$.

Age is another important factor that contributes to the risk independently of BMD. The risk of osteoporotic fracture increases significantly with the age for both men and the women. In addition, for each value of BMD, fracture risk is much higher in the elderly then in young people. In women, risk of osteoporotic VCF increases 6-fold from the menopause to age 85.A previous VCF is an important risk factor for the subsequent vertebral fracture.

Pain relief in vertebroplasty is by thermal \& mechanical effect. The thermal effect postulated as a cause of pain reduction due to neurolysis of vertebral and periosteal neural transmission. The mechanical effect is a cause of pain relief minimising micromotion of vertebral fracture which would stimulate pain nociceptors

Bone scan and MRI is helpful to determine the age of a compression fracture, especially when history is negative for trauma or fall. however bone scan may not show a fracture for upto 10 days after an acute injury. MRI usually shows decreased the signal on T1 sequences and marrow edema on T2 fat saturation sequences at fracture site

When VCF has been diagnosed, it is important to distinguish between osteoporotic and tumour associated fractures. To rule out the malignant nature of fracture, MRI can be the helpful because presence of a soft tissue mass or the pedicle involvement is suggestive of tumour.

\section{Case 1}

Preop L2, L3 osteoporotic compression fracture
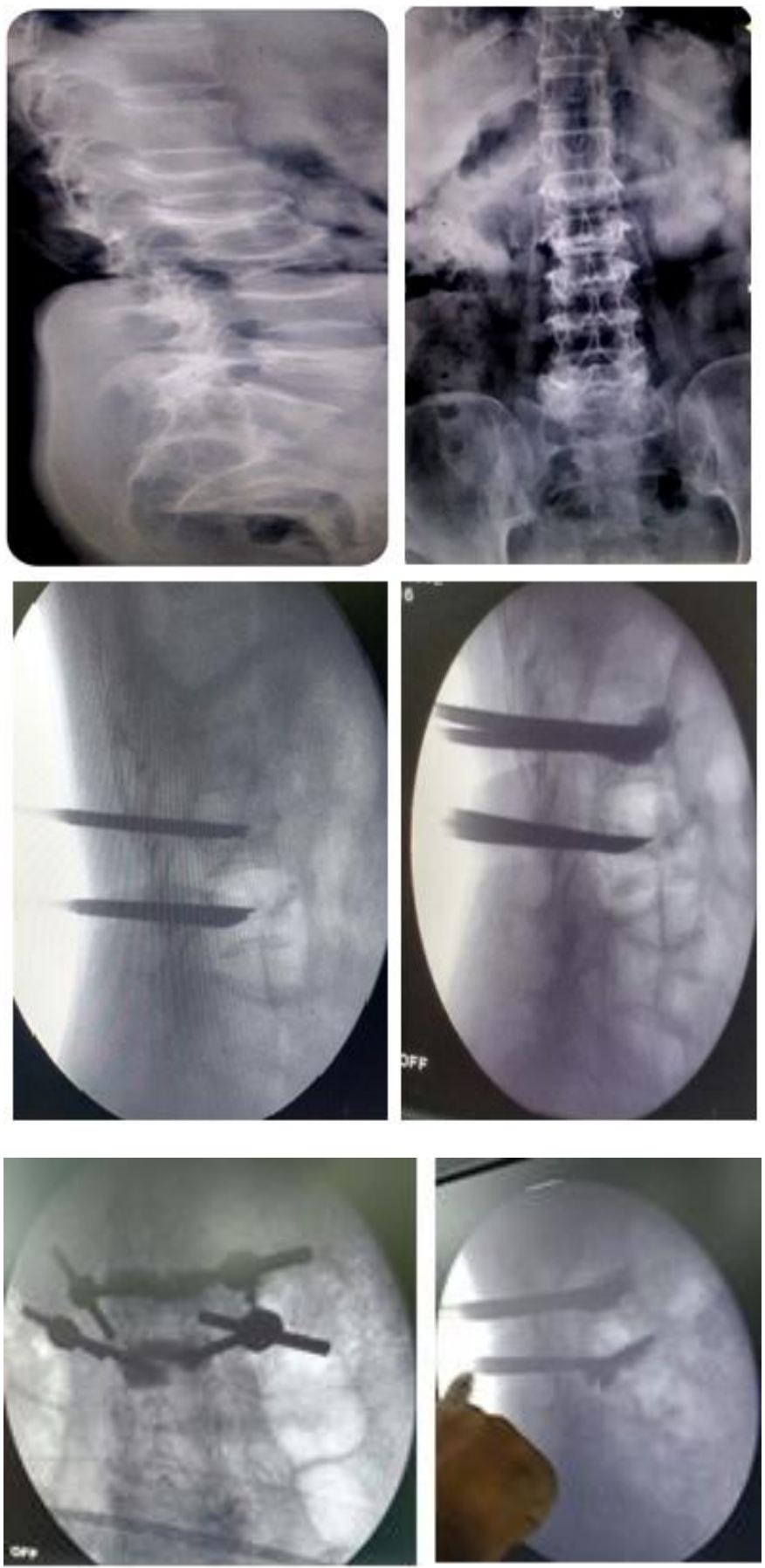

Immediate Post op 


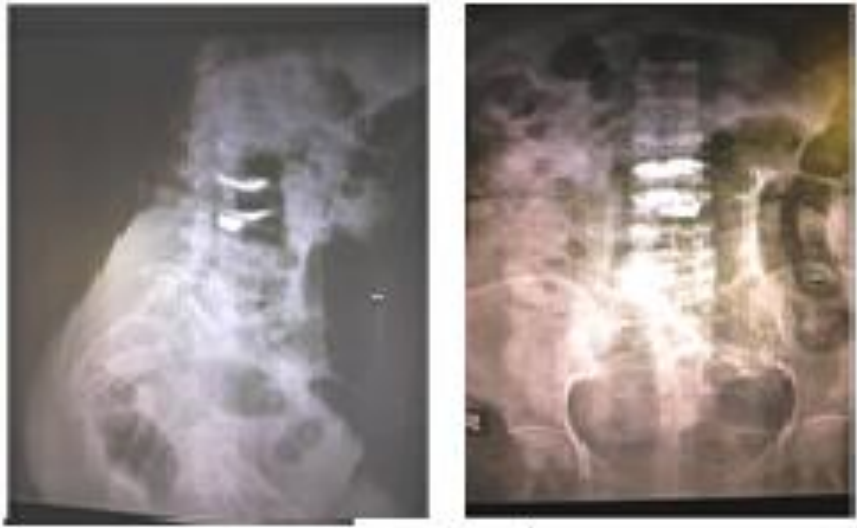

Follow up third month

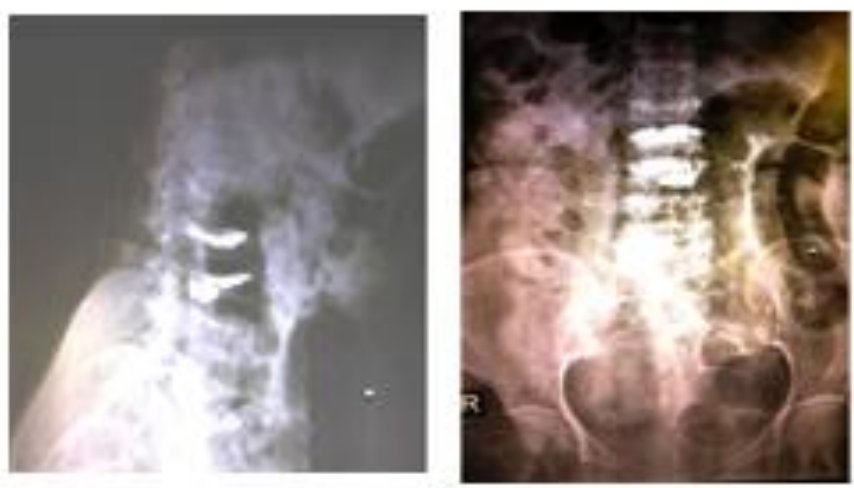

Follow up one year
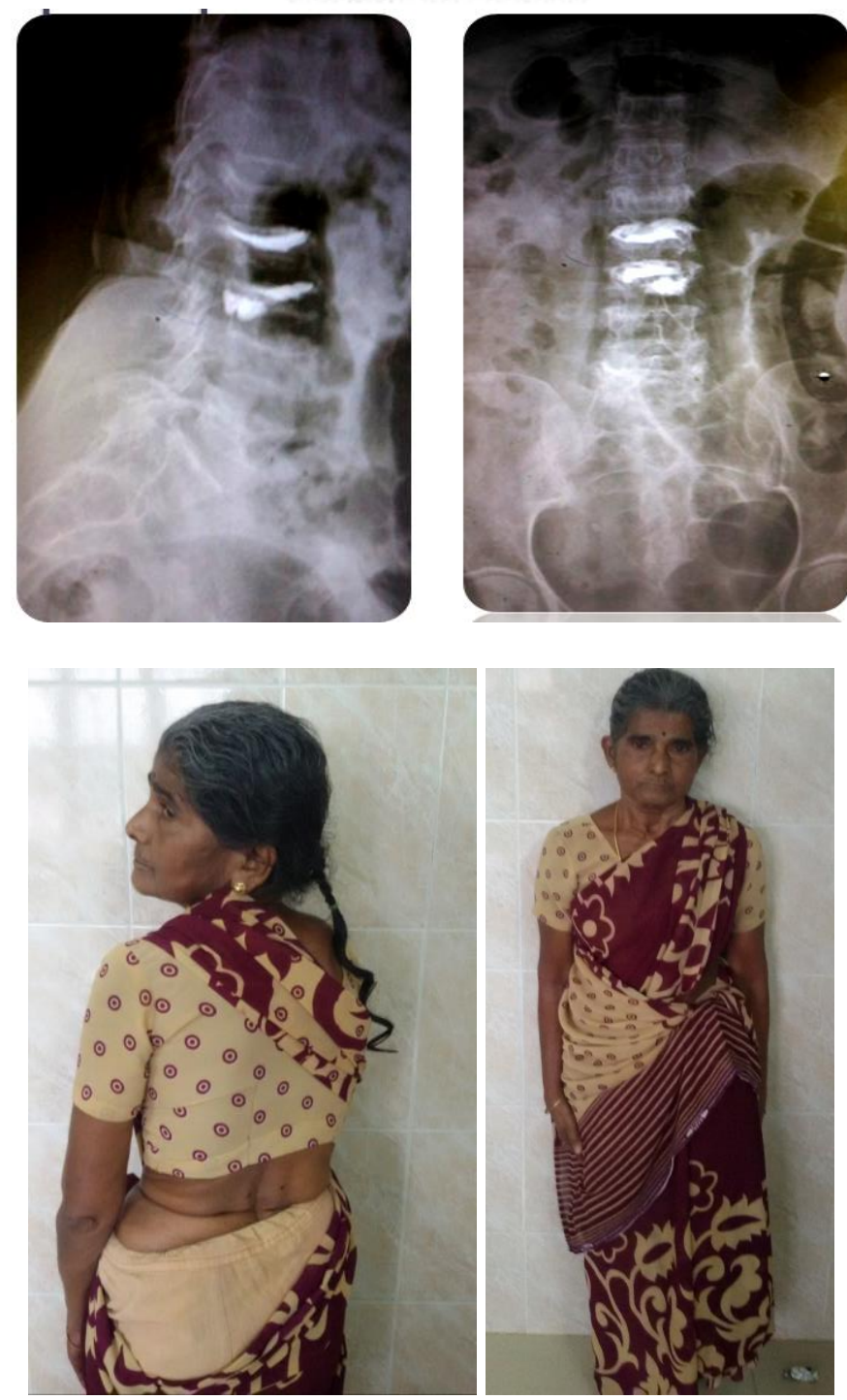

Case 2

Preop D12osteoporotic compression fracture
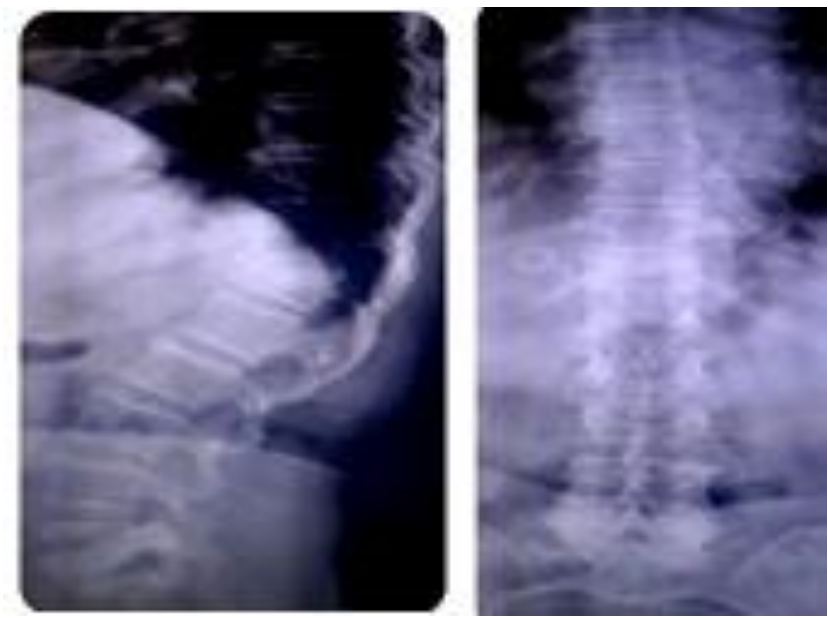

Postop D12osteoporotic compression fracture
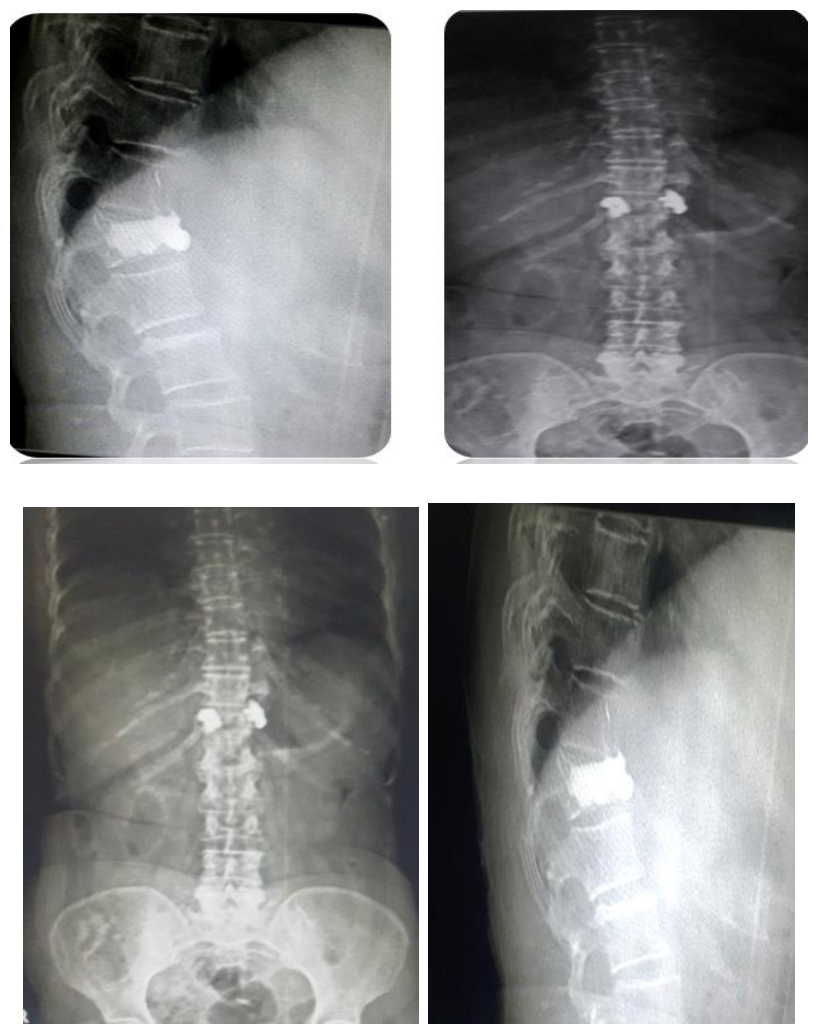

\section{One Year Follow up}
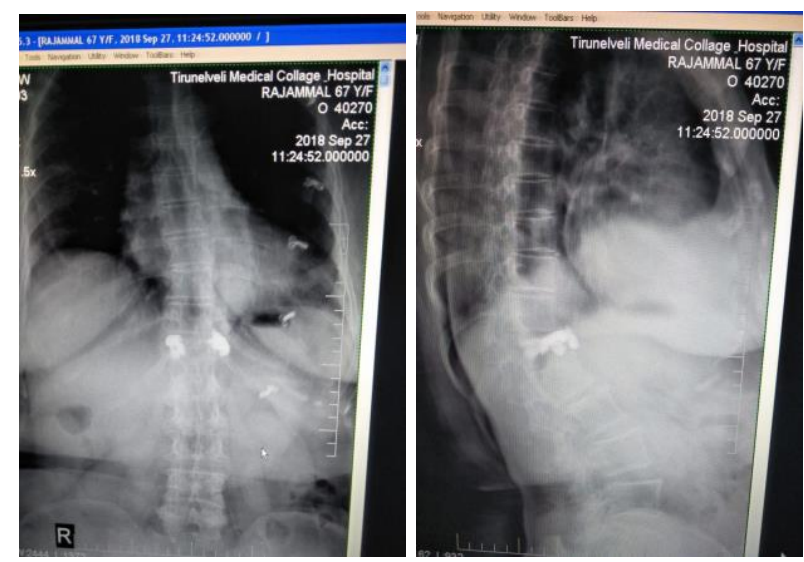


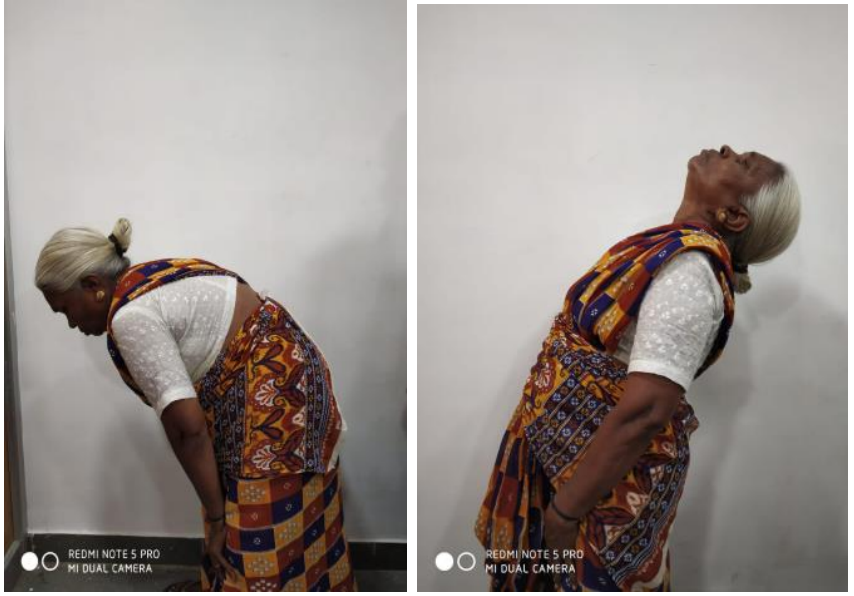

\section{Conclusion}

Percutaneous vertebroplasty is a technically feasible treatment in patients with osteoporotic compression fractures which doesn't respond to the best possible conservative treatment. Percutaneous vertebroplasty works as internal splint for the microfractures of vertebral body by methyl methacrylate cement which helps to relief severe pain. The pain relief and the improvement of deformity, mobility, function and stature after percutaneous vertebroplasty is immediate Successful treatment depends largely on appropriate patients selection, preoperative assessments, proper planning, meticulously performed procedure.

In our opinion, the percutaneous vertebroplasty is an extremely useful procedure in the management of complications of vertebral compression fractures including severe pain and vertebral deformity. Modification in conventional technique of vertebroplasty significantly decreases the incidence of cement leakage during the procedure.

\section{References}

1. Galimbert P, Deramond H, Rosat $\mathrm{P}$ et al. Preliminary note on the treatment of vertebral angioma by percutaneous acrylic vertebroplasty. Neurochirurgie. 1987; 33:166-168.

2. John M Mathis, John D Barr, Stephen M Belkoff, Michelle S Barr, Mary E Jensen, Herve' Deramond. Percutaneous Vertebroplasty: A Developing Standard of Care for Vertebral Compression Fractures, AJNR Am J Neuroradiol. 2001; 22:373-381.

3. Deramond H, Depriester C, Galibert P, Le Gars D. Percutaneous vertebroplasty with polymethylmethacrylate: technique, indications and results. Radiol Clin North Am. 1998; 36:533-546.

4. Harper EJ, Bonfield W. Tensile characteristics of ten commercial acrylic bone cements. J Biomed Mater Res. 2000; 53:605-616

5. Belkoff SM, Maroney M, Fenton DC, Mathis JM. An in vitro biomechanical evaluation of bone cements used in percutaneous vertebroplasty [Suppl]. Bone. 1999; 25:S23-S26

6. Jasper LE, Deramond H, Mathis JM, Belkoff SM. The effect of monomer-to-powder ratio on the material properties of Cranioplastic [Suppl]. Bone. 1999; 25:S27S29.

7. Deramond H, Depriester C, Galibert P, Le Gars D. Percutaneous vertebroplasty with polymethylmethacrylate: technique, indications, and results. RadiolClin North Am. 1998; 36:533-546.
8. Jensen ME, Evans AJ, Mathis JM, Kallmes DF, Cloft HJ, Dion JE. Percutaneous polymethyl methacrylate vertebroplasty in the treatment of osteoporotic vertebral body compression fractures: technical aspects. AJNR Am J Neuroradiol. 1997; 18:1897-1904.

9. Haas SS, Brauer GM, Dickson G. A characterization of polymethylmethacrylate bonecement. J Bone Joint Surg. 1975; 57A:380-391.

10. Combs SP, Greenwald AS. The effects of barium sulfate on the polymerization temperature and shear strength of surgical Simplex P. ClinOrthop. 1979; 145:287-291.

11. deWijn JR, Slooff TJ, Driessens FC. Characterization bone cements. Acta Orthop Scand. 1975; 46:38-51.

12. Sabokbar A, Fujikawa Y, Murray DW, Athanasou NA. Radioopaque agents in bone cement increase bone resorption. J Bone Joint Surg. 1997; 79B:129-134.

13. Wimhurst JA, Brooks RA, Rushton N. The effects of particulate bone cements at the bone-implant interface. J Bone Joint Surg. 2001; 83B:588-592.

14. Deramond H, Wright NT, Belkoff SM. Temperature elevation caused by bone cement polymerization during vertebroplasty [Suppl]. Bone. 1999; 25:S17-S21.

15. Eriksson RA, Albrektsson T, Magnusson B. Assessment of bone viability after heat trauma: a histological, histochemical and vital microscopic study in the rabbit. Scand J Plast Reconstr Surg. 1984; 18:261-268.

16. Kallmes DF, Jensen ME. Percutaneous vertebroplasty. Radiology. 2003; 229:27-36.

17. Shinzato S, Nakamura $T$, Kokubo $T$, Kitamura $Y$. Bioactive bone cement: effect of silane treatment on mechanical properties and Osteoconductivity. J Biomed Mater Res. 2001; 55:277-284.

18. Yamamuro T, Nakamura T, Iida $\mathrm{H}$ et al. Development of bioactive bone cement and its clinical applications. Biomaterials. 1998; 19:1479-1482.

19. Gangi A, Kastler BA, Dietemann JL. Percutaneous vertebroplasty guided by a combination of CT and fluoroscopy. AJNR. 1994; 15:83-86.

20. Mary E Jensen, Avery J Evans, John M Mathis, David F Kallmes, Harry J Cloft, Jacques E Dion. Percutaneous Polymethylmethacrylate Vertebroplasty in the Treatment of Osteoporotic Vertebral Body Compression Fractures: Technical Aspects. AJNR Am J Neuroradiol. 1904-1997; 18:1897-1904.

21. Doris DM Lin, Philippe Gailloud MD, Kieran J Murphy. FRCPC. Percutaneous Vertebroplasty in Benign and Malignant Disease. Neurosurgery Quarterly, 2001, 11(4).

22. Kim AK, Jensen ME, Dion JE, Schweickert PA, Kaufmann TJ, Kallmes DF. Unilateral Transpedicular vertebroplasty: initial expirence. Radiology. 2002; 222:737-741.

23. Schallen EH, Gilula LA. Vertebroplasty: Reusable flange converters with hub lock for injection of polymethylmethacrylate in to screw plunger spring. Radiology. 2002; 222:851-855.

24. Seasy M, Dousset V, Liguoro D et al. Intraosseous Lidocaine provide effective analgesia for percutaneous veretebroplasty of osteoporotic fractures. Can J Anesth. 2002; 49(2):137-143.

25. Weill A, Chiras J, Simon JM et al. Spinal metastasis: indications for the results of percutaneous example of acrylic surgical cement. Radiology. 1996; 199:241-247.

26. Jones JO, Bruel BM, Vattam SR. Management of painful vertebral hemangiomas with kyphoplasty: A report of two cases and a literature review. Pain Physician. 2009; 
12:E297-303.

27. Suparna HC, Vadhiraja BM, Apsani RC et al. Symptomatic vertebral hemangiomas - results of treatment with radiotherapy. Ind J RadiolImag. 2006; 16:37-40.

28. Chen L, Zhang CL, Tang TS. Cement vertebroplasty combined with ethanol injection in the treatment of vertebral hemangioma. Chin Med J. 2007; 120:11361139.

29. Loredo JD, Reinze D, Bard $\mathrm{M}$ et al. Vertebral hemangiomas: radiolagic evaluation. Radiology Fox MW, Onoprio BM. The natural history and management of symptomatic \& asymptomatic vertebral hemangioms. J Neurosurgery. 1986; 161:183-189. 